\title{
Biomarkers and Ultrasound in the Knee Osteoarthrosis Diagnosis
}

\author{
Sandra Živanović1, Ljiljana Petrović Rackov² and Zoran Mijušković3 \\ ${ }^{1}$ Medical Faculty University of Kragujevac, Helth centre of Kragujevac, Rheumatology, \\ ${ }^{2}$ Clinique for Rheumatology and Clinical Immunology, \\ Military Medical Academy Belgrade, \\ ${ }^{3}$ Institute for Biochemistry, Military Medical Academy Belgrade, \\ Serbia
}

\section{Introduction}

This study will present contemporary methods of the knee osteoarthrosis (OA) diagnosis arthrosonography and biomarkers, which are applied and recommended in the modern practice.

Advantages of ultrasound diagnostics (arthrosonography) and serum biomarkers in rheumatologic diagnostics will be documented through this research which applied these methods. Ultrasound has become an integral part of clinical practice and is applied in many fields of medicine, however, in rheumatology it has not been fully recognized yet. Appliance of biomarkers in knee osteoarthrosis diagnosis is considerably a more expensive method, and has not been usually used for this purpose. It is very precise though in detection of changes in knee joint with osteoarthrosis.

The goal of this study is to affirm the ultrasound diagnostic method for many advantages it has comparing to other methods which have been used as routine, and to recommend it as a important part of clinical rheumatologic checkup.

The following methods are usually used for visualisation of knee joint: radiography, nuclear magnet resonance, computerised tomography, arthroscopy and arthrography. The most commonly applied and routine diagnostic method is radiography. However, the conventional radiography and computerised tomography are the methods without possibility of direct visualisation of the joint cartilage. Narrowing of the joint area is only an indirect indication of a joint damage, and early changes on the cartilage cannot be evaluated (Batalov et al.,2000). Nuclear magnetic resonance provides direct information on changes in different joint tissues, which is why it is nowadays appropriate for the knee osteoarthrosis diagnosis. However, its appliance is limited due to the very expensive medical examination. Methods of direct visualisation of the joint cartilage are arthrography and arthroscopy, which are less used in clinical practice, due to their invasiveness and limited indications.

\section{Contemporary diagnostics of the knee osteoarthrosis}

Ultrasound examination is non-invasive and much more accessible for evaluation of a large number of patients than other imaging modalities. The European League Against 
Rheumatism in the first and second part of the Report from 2005 (D'Agostino et al., 2005, Conaghan et al 2005) recommends ultrasound medical technique as a golden standard in diagnosis of pathological changes in the knee joint, and also recommends arthrosonographic measuring and techniques.

This study will present results of the prospective research, which comprises 88 patients with diagnosis of primary knee osteoarthrosis, according to criteria of the American College of Rheumatology - ACR. Information about pain intensity in the knee was obtained from the patients through anamnesis during the last two weeks, measuring the frequency and intensity of pain during the night, as well as stiffness after a period of rest. Pain intensity was numerically evaluated marking the pain spots on VAS from $0-100 \mathrm{~mm}$. Clinical examination of the both knees determined presence or absence of abnormal knee fluid buildup (arthritis) which was evaluated as serious, moderate, minimal or absent, as well as presence or absence of the Baker's cyst. The knee function was evaluated according to the scope of flexion in degrees. Based on HAQ index, the overall health condition of patients was assessed, and the functional ability marked as moderate or serious inability and the need for nursing and assistance. An ultrasound examination of the both knees in the B mode was done by a two rheumatologist on SDU - 1200 device, using a linear probe of $10 \mathrm{MHz}$. Frontal longitudinal view was used to determined presence or absence of synovial inflammation indicators: effusion - defined as the scope of fluid buildup larger than $4 \mathrm{~mm}$ in the knee suprapatellar, medial or lateral recess (SR, MR, LR); synovitis - defined as thickening of synovial membrane over $4 \mathrm{~mm}$.

The maximal depth of effusion and thickness of synovial tissue were measured and presented in $\mathrm{mm}$. Morphologically, effusion was marked as absent or present in suprapatellar, medial or lateral knee recess, while synovitis was marked as absent or present (in nodular, difusal or nodular-difusal mode). Arthrosonography determined existence and size of the Baker's cyst behind the knee joint, as well as existence and thickness of synovitis inside it. Measurement of cartilage thickness was conducted in transversal view at medial and lateral femur condyle, at 90 degree knee bend, and posterior longitudinal view at medial femur condyle when the knee was extended (in $\mathrm{mm}$ ). The existence and size of osteophytes (denoted as shorter or $\leq 2 \mathrm{~mm}$, and longer or $\geq$ $2 \mathrm{~mm}$ ) and bone erosions were established by lateral view on femur and tibia medial and lateral condyles. Analysis of serum samples determined concentration of COMP $(\mathrm{ng} / \mathrm{ml})$, YKL - 40 (ng/ml) and CTX-I (ng/ml) by ELISA (Enzyme-Linked ImmunoSorbent Assay) methods, using Cartilage Oligo Metric Protein kit (Euro-diagnostica Wieslab tm hCOMP quantitative kit), YKL-40 for Rheumatology and Oncology kit (Quidel, Metra- YKL-40 EIA kit) and Serum Crosslaps (Nordic Bioscience Diagnostica). The research excluded the patients who had the knee damage six months before the research, the patients with the total or partial endoprosthesis or the knee joint osteotomy, with arthroscopy of the knee joint in the past year, and the patients who had been treated with intraarticularly injected corticosteroids or hondroprotective four weeks before enrollment into the research.

Due to appliance of YKL-40 biomarkers, it was also necessary to exclude the patients with rheumatoid arthritis, inflammatory intestinal diseases, bacterial infections, liver fibrosis and malignant diseases. Presentation of these results will be compared with the results of other researches in this field. The advantages of ultrasound diagnostic methods and biomarkers will be documented as contemporary knee osteoarthrosis diagnostic methods in clinical practice. 


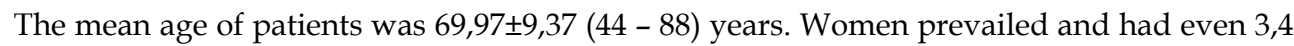
times more frequent osteoarthrosis than men, which complies with the data available in literature, according to which osteoarthrosis is more frequent in female subjects (Hart et al., 1999). Duration of the knee osteoarthrosis in the patients enrolled this study was $6,46 \pm 6,73$ (0,5-37), which indicates initiation of osteoarthrosis in certain patients between 40 and 50 years of age. Epidemiological researches have shown that in the developed countries $50 \%$ of population older than 40 can prove arthritic joint changes, but are mainly without symptoms at this age.

\subsection{Clinical evaluation of the knee osteoarthrosis deterioration parameters}

Knee osteoarthrosis deterioration evaluation is usually done by clinical estimation of the pain intensity according to Dougados (Dougados et al,.1997), which implies estimation of the pain intensity in the knee, estimation of the pain occurring during the night, and presence of fluid buildup (effusion) in knee joint. According to Dougados, estimation of the pain intensity in the knee is done by indication on the part of the patients experiencing the pain, using the pain VAS $(0-100 \mathrm{~mm})$ and by clinical estimation of knee osteoarthrosis degree on the part of medical doctors according to VAS for overall estimation of the disease degree (0-100 mm). Mean value of the pain intensity on VAS was $58,86 \pm 22,56$. The medical doctor's evaluation of the clinical degree of osteoarthrosis on VAS (mm) was $40,45 \pm 18,31$ average.

Among the subjects, only the patients with deterioration and evaluation on VAS over $30 \mathrm{~mm}$ expirienced stiffness longer than $30 \mathrm{~min}$. as well as the night pain. Clinical examination determined knee fluid buildup in $54(61,3 \%)$ of the patients. Fifteen patients $(17 \%)$ had the Baker's cyst. Based on the clinical evaluation of knee osteoarthrosis deterioration according to Dougados, all the patients were divided in two groups: 74 patients with knee osteoarthrosis deterioration and pain mark over $30 \mathrm{~mm}$ on VAS, and 14 patients without deterioration and pain mark below $30 \mathrm{~mm}$ on VAS.

Comparing the groups of patients with and without knee osteoarthrosis deterioration, with reference to the years of age $(p=0,118)$ and duration of disease $(p=0,211)$ no significant difference was indicated. The mean age of patients and duration of disease were similar in the both groups of surveyed patients.

Increased body weight, verified by the higher BMI is associated with incidence and progression of knee osteoarthrosis, according to the results of the Rotterdam study (Reijman et al.,2007). Even $81,8 \%$ of knee osteoarthrosis patients had the body weight over the optimum. The patients with pain intensity mark over $30 \mathrm{~mm}$ on the pain VAS had higher body weight - BMI $29,37 \pm 1,08 \mathrm{~kg} / \mathrm{m}^{2}$ than the patients with smaller knee pain intensity - BMI $25,04 \pm 2,46 \mathrm{~kg} / \mathrm{m}^{2}(\mathrm{p}=0,000)$. In this way, it was confirmed that the excessive body weight is the risk factor which contributes to deterioration of knee osteoarthrosis.

The knee fluid buildup is a clinical characteristic of osteoarthrosis, which most commonly occurs in progressive osteoarthrosis, but can also often occur at the initial phases of OA during the periods of disease deteriorating. In the group of patients with the deteriorated knee osteoarthrosis and the pain mark over $30 \mathrm{~mm}$ on VAS, $29,7 \%$ of the patients were without abnormal fluid buildup, while in the group of patients without osteoarthrosis deterioration, there were significantly more patients without fluid buildup $(85,71 \%)$. Minimal fluid buildup was present at $37,8 \%$ of the patients with the pain mark over $30 \mathrm{~mm}$ on VAS. The result of moderate fluid buildup was confirmed by a clinical examination of 
$27 \%$ of the patients, and of the serious fluid buildup in $5,4 \%$ of the patients, in the group of patients with osteoarthrosis deterioration. In the group of patients without osteoarthrosis deterioration neither moderate nor serious knee fluid buildups were detected. Baker's cyst was diagnosed by clinical examination in $18,1 \%$ of the patients with the pain mark over 30 mm on VAS and 7,1\% of the patients with lesser pain intensity (Figure 1.). It was concluded that the pain intensity marked on VAS by the patients considerably differed when minimal, moderate or serious knee fluid buildup was found by the clinical examination, or it was absent $(p=0,014)$, which confirms that inflammation contributes to stronger pain in the knee joint (Živanović et al.,2009).

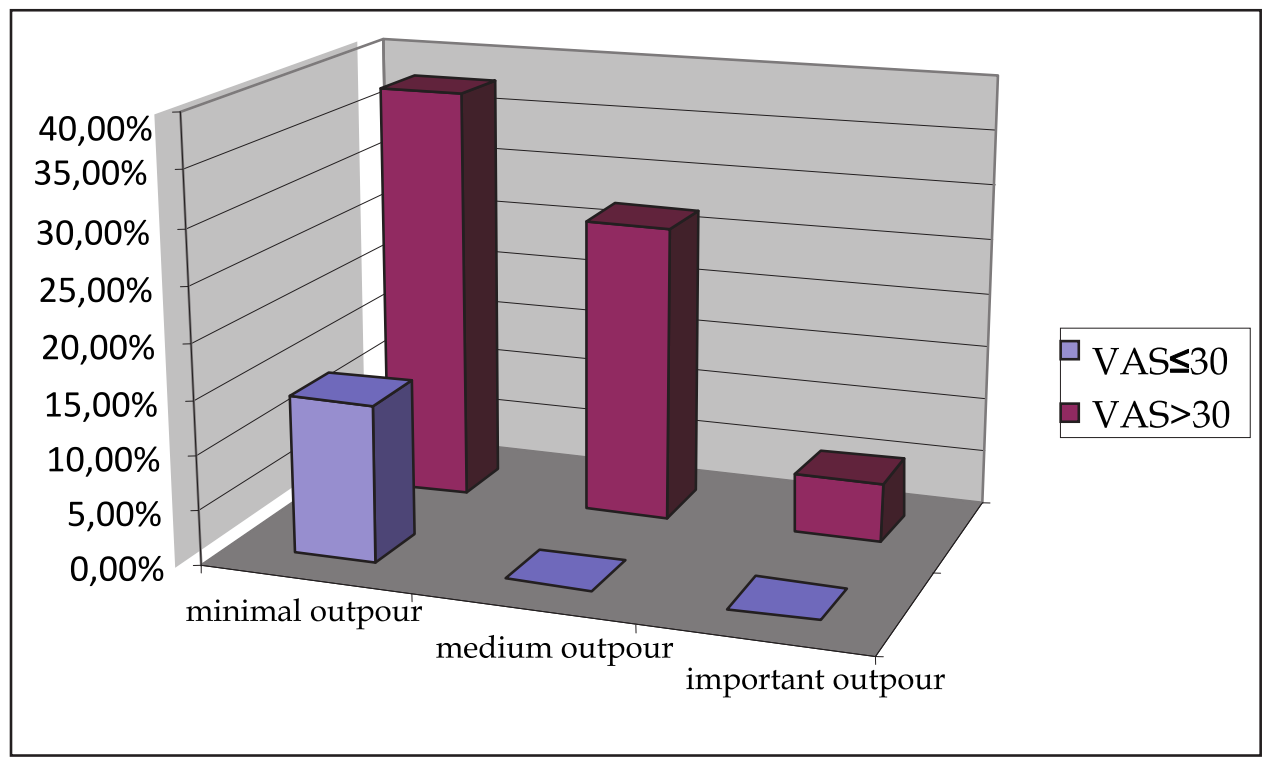

Fig. 1. Comparison of the size of outpour (minimal, medium and important) between the patients with pain scores greater and lower than $30 \mathrm{~mm}$ on VAS pain scale

The fact was confirmed that small and large crepitations occur in deteriorated osteoarthrosis, with the presence of both stronger pain and synovial inflammation. The patients with deteriorated osteoarthrosis and stronger pain had significantly limited movements in the knee joint, comparing to patients without deterioration, as expected. A survey of the health condition confirmed higher degree of inability in the patients with deteriorated knee osteoarthrosis comparing to the patients without symptoms and indicators of deterioration, which complies with the data obtained from literature.The patients with more intensive pain and problems are more weighty, have limited knee movements and higher degree of inability, and vice versa.

Longer duration of the disease causes more difficult clinical form of the disease, and the bigger body weight is associated with the doctors' estimation of a more difficult form of the disease. In the presence of a serious knee fluid buildup, doctor evaluates osteoarthrosis difficulty with the highest mark, as well as if reduced mobility is detected at a clinical examination and synovitis in suprapatellar recess detected on ultrasound. 


\subsubsection{Ultrasound diagnostics of inflammatory changes in the knee osteoarthrosis}

The average values of the size of effusion and synovitis in osteoarthrosis patients are highest in lateral recess, comparing to the values of same parameters in medial recess and suprapatellar recess. Based on the data that most of patients had effusion in lateral recess, and that clinically established moderate or minimal effusion is arthrosonographically shown as effusion only in lateral recess, it was concluded that inflammation most frequently occurs in this recess (Figure 2.).

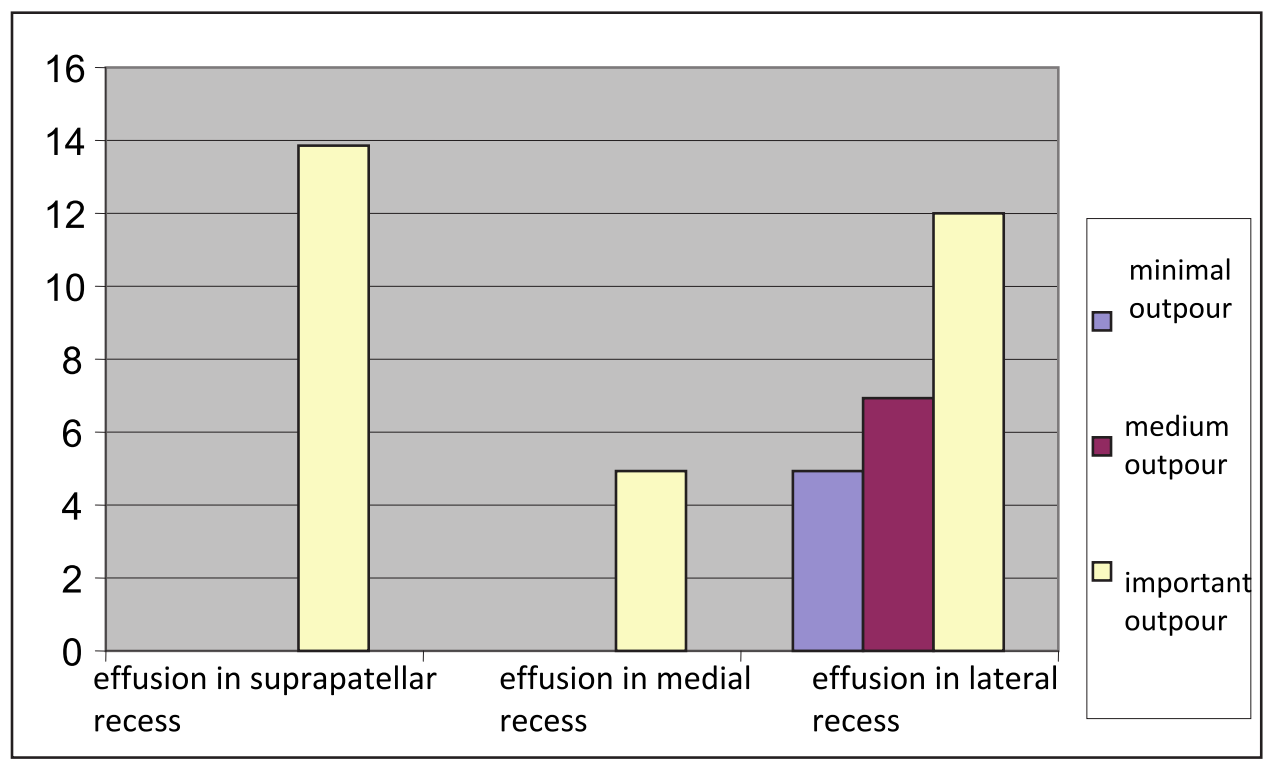

Fig. 2. Comparison of the middle value (median) size of effusion in suprapatellar, medial and/or lateral recess between patients with absent, minimal, medium and important outpour

It was found that synovitis in suprapatellar recess causes serious effusion in all three knee recess and reflects intensive inflammation in the knee joint. Besides, synovitis in medial and lateral recess can cause effusion in the local recess, with suprapatellar extending (Figure 3.) (Živanović et al.,2009).

Duration of disease does not influence appearance, size and locality of synovial inflammation, nor its deterioration in the patients with knee joint osteoarthrosis.

Effusion at the clinical examination was present in $61,3 \%$ of the patients, while arthrosonographic examination found effusion in $75,0 \%$ of the patients. There is a significant difference between the frequencies of clinically found effusion (the knee fluid buildup) and presence of effusion found by arthrosonography, in the patients with knee osteoarthrosis $(p=0,000)$. Six patients $(11,1 \%)$ had clinical effusion, but not an ultrasound confirmed effusion. It is also important that in $52,9 \%$ of the patients effusion was not clinically found, but ultrasound determined its presence. Based on the facts presented above, it was established that sensitivity of clinical diagnosis of effusion is $73 \%$ (percentage of diagnosis of effusion by clinical examination in the group of patients who had effusion proved by 
ultrasound), while specificity of clinical diagnosis of effusion is $73 \%$ (percentage of diagnosis of effusion by clinical checkup in the group of patients who had no effusion proved by ultrasound) (Table 1.) (Živanović et al.,2009).

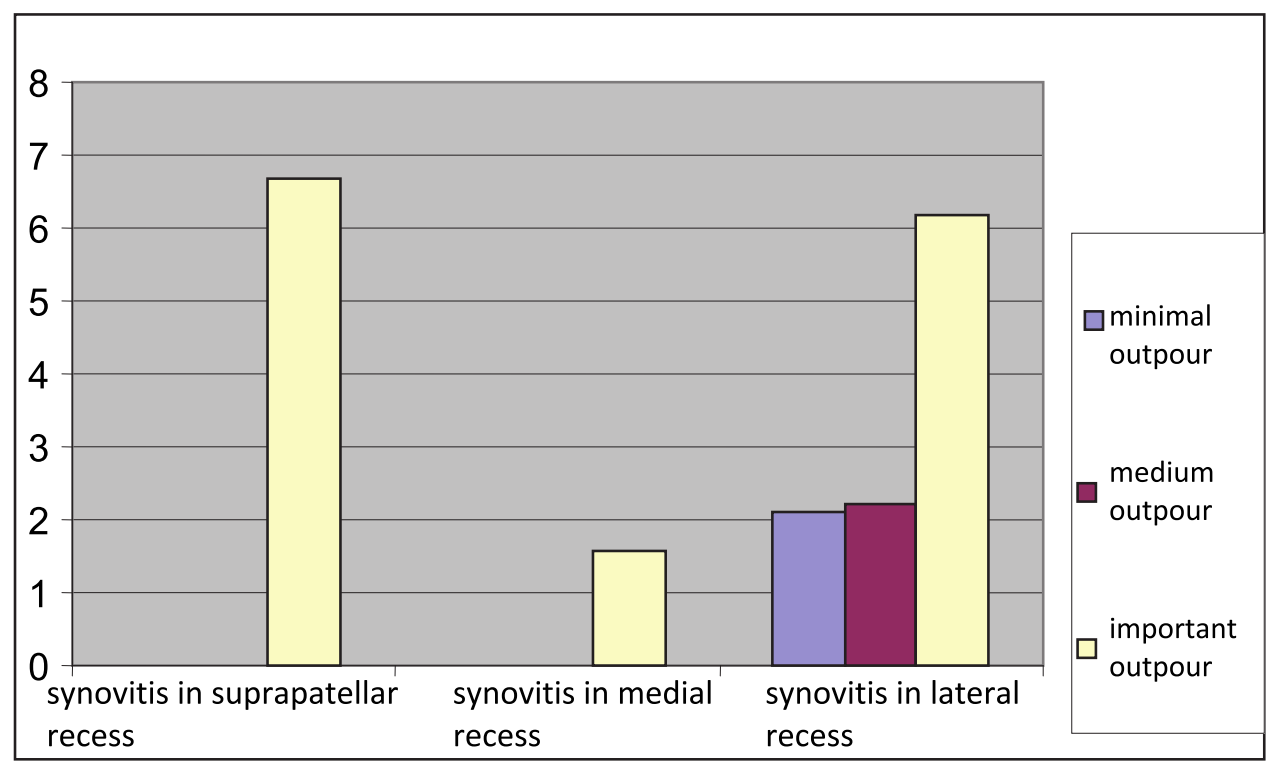

Fig. 3. Comparison of the middle value (median) thicknees of synovitis in suprapatellar, medial and/or lateral recess between patients with absent, minimal, medium and important outpour

\begin{tabular}{|c|c|c|c|c|c|c|}
\hline \multirow{3}{*}{$\begin{array}{l}\text { clinical } \\
\text { findings } \\
\text { of } \\
\text { effusion }\end{array}$} & \multicolumn{6}{|c|}{ Ultrasound findings of effusion } \\
\hline & \multicolumn{2}{|c|}{ absent } & \multicolumn{2}{|c|}{ present } & \multicolumn{2}{|c|}{ total } \\
\hline & $\begin{array}{l}\text { Number } \\
\text { of patient }\end{array}$ & $\%$ & $\begin{array}{l}\text { Number } \\
\text { of patient }\end{array}$ & $\%$ & $\begin{array}{l}\text { Number } \\
\text { of patient }\end{array}$ & $\%$ \\
\hline absent & 16 & 47,05 & 18 & 52,94 & 34 & 100 \\
\hline present & 6 & 11,11 & 48 & 88,88 & 54 & 100 \\
\hline total & 22 & 25,0 & 66 & 75,0 & 88 & 100 \\
\hline & & & & & & $p=0,000$ \\
\hline
\end{tabular}

Table 1. The frequency of clinical findings of effusion, and ultrasound-term findings of effusion in patients with knee OA

Kane et al. recommend arthrosonography as the golden standard, because it is more sensitive than clinical checkup of the joint diseases, and suspect the precision on acurateness of detecting standardised Disease Activity Scores (DAS) based only on a clinical checkup (Kane et al.,2003). 


\subsubsection{The ultrasound parameter of the knee osteoarthrosis deterioration - Joint effusion and synovial proliferation}

Hill's research showed that moderate and serious effusions and synovial proliferation in the joint cause pain in the patients with knee osteoarthrosis (Hill et al.,2001).

The knee pain intensity differs comparing to presence or absence of effusion found by ultrasound, regardless its location. It was established that effusion and synovial inflammation contribute to increase of pain in patients with knee osteoarthrosis.

The average values of effusion size and synovial membrane thickness in the knee recess were higher in group of patients with the signs of knee arthrosis deterioration and the pain mark above $30 \mathrm{~mm}$ on VAS (Figure 4.5.).

The largest effusion and synovitis occurred in the lateral recess. It is important that ultrasound also detected effusion in over $63 \%$ of patients with osteoarthrosis deterioration, but without clear clinical signs of effusion. The facts presented above indicate that ultrasound is more sensitive method than clinical examination at detection of synovial inflammation, especially in the patients with intensive pain, and without clinical signs of effusion.

In the analyzed group of patients with osteoarthrosis, most of the patients had synovial inflammation in lateral recess and intensity of pain in the knee was related to the size of effusion and synovitis present in lateral recess (Table 2.,3.).

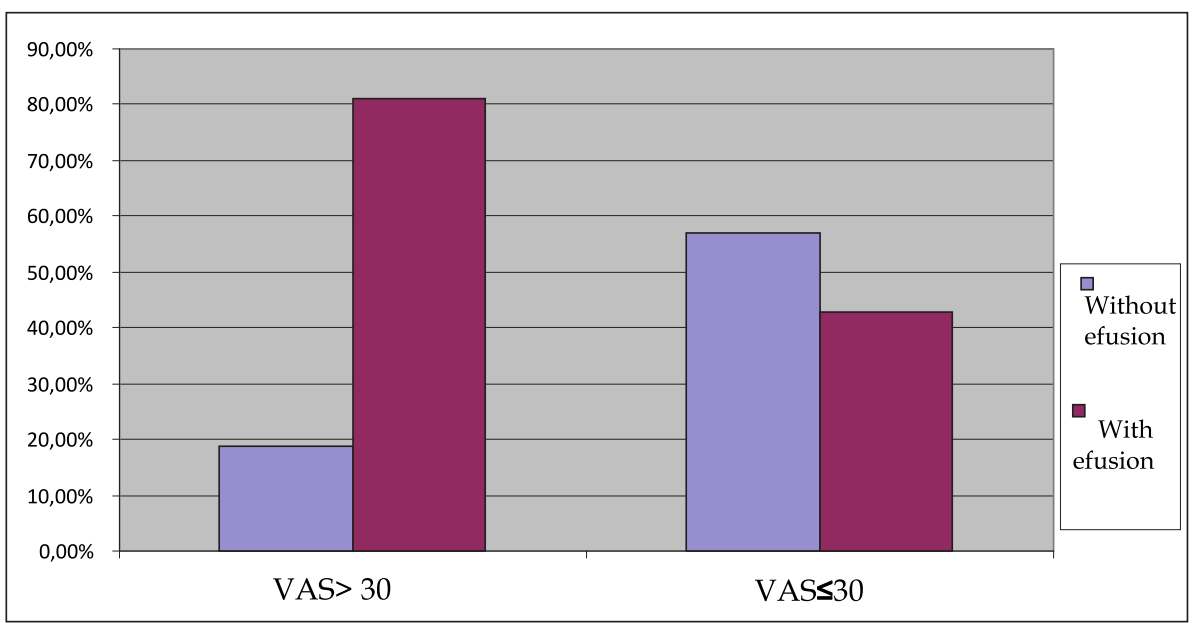

Fig. 4. The presence or absence of effusion in patients with pain score greater than $30 \mathrm{~mm}$ on the VAS pain scale and with less than $30 \mathrm{~mm}$ on VAS pain scale 


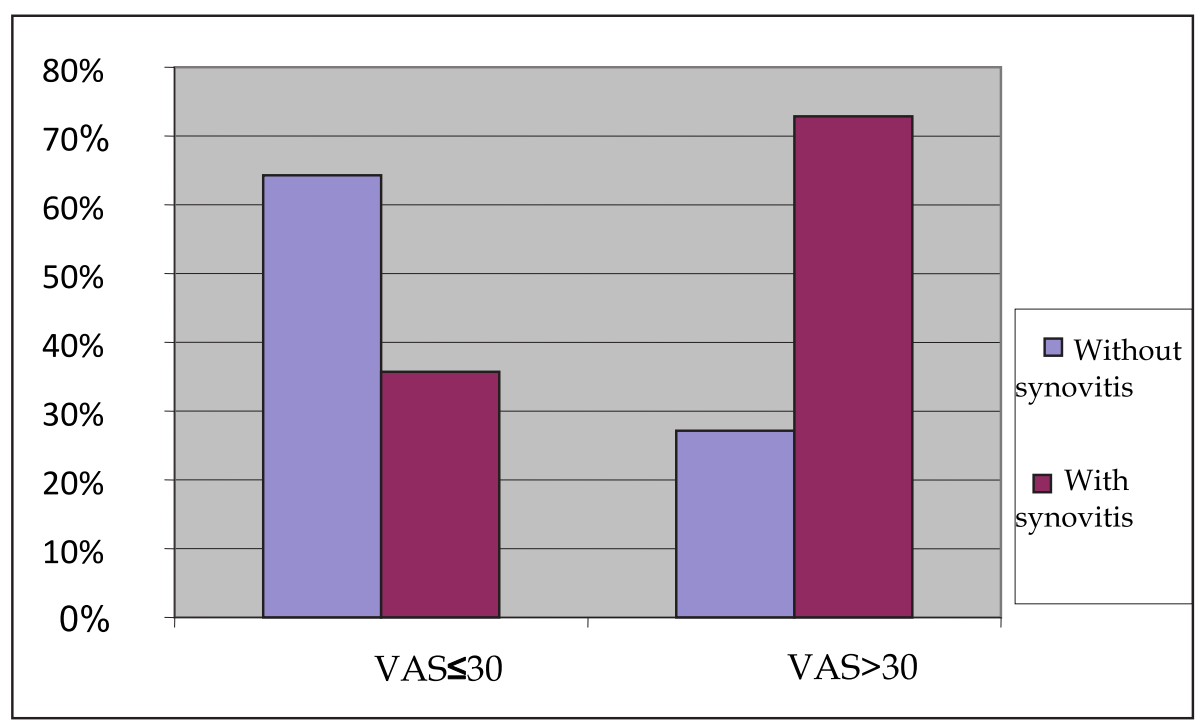

Fig. 5. The presence or absence of synovitis in patients with pain score greater than $30 \mathrm{~mm}$ on the VAS pain scale and with less than $30 \mathrm{~mm}$ on VAS pain scale

\begin{tabular}{|c|c|c|c|}
\hline \multirow{2}{*}{ VAS } & \multicolumn{3}{|c|}{$\begin{array}{c}\text { effusion in suprapatellar } \\
\text { recess (mm) }\end{array}$} \\
\cline { 2 - 4 } & 25-th per & medijan & 75-th per \\
\hline$>30$ & 0 & $\mathbf{0}$ & $\mathbf{6 , 1 2}$ \\
\hline$\leq 30$ & 0 & $\mathbf{0}$ & $\mathbf{0}$ \\
\hline & & & $\mathrm{p}=0,123$ \\
\hline
\end{tabular}

\begin{tabular}{|c|c|c|c|}
\hline \multirow{2}{*}{ VAS } & \multicolumn{3}{|c|}{$\begin{array}{c}\text { effusion in medial } \\
\text { recess }(\mathrm{mm})\end{array}$} \\
\cline { 2 - 4 } & 25-th per & medijan & 75-th per \\
\hline $\mathbf{3 0}$ & 0 & $\mathbf{0}$ & $\mathbf{5 , 0 9}$ \\
\hline$\leq \mathbf{3 0}$ & 0 & $\mathbf{0}$ & $\mathbf{0}$ \\
\hline & & & $\mathrm{p}=0,015$ \\
\hline
\end{tabular}

\begin{tabular}{|c|c|c|c|}
\hline \multirow{2}{*}{ VAS } & \multicolumn{3}{|c|}{$\begin{array}{c}\text { effusion in lateral } \\
\text { recess }(\mathrm{mm})\end{array}$} \\
\cline { 2 - 4 } & 25-th per & medijan. & 75 -th per \\
\hline$>30$ & 0 & $\mathbf{4 , 8 3}$ & $\mathbf{7 , 7 1}$ \\
\hline$\leq 30$ & 0 & $\mathbf{0}$ & $\mathbf{4 , 4 1}$ \\
\hline & & & $\mathrm{p}=0,010$ \\
\hline
\end{tabular}

Table 2. Comparation average value of a quantity of effusion in suprapatellar, medial and lateral recess between the patients with pain scores greater and lower than $30 \mathrm{~mm}$ on VAS pain scale 


\begin{tabular}{|c|c|c|c|c|c|c|c|}
\hline \multirow{2}{*}{ VAS } & \multicolumn{7}{|c|}{$\begin{array}{c}\text { synovitis in suprapatellar } \\
\text { recess (mm) }\end{array}$} \\
\cline { 2 - 9 } & 5-ti per & 10-ti per & 25-ti per & medijan. & 75 -ti per & 90 -ti per & 95 -ti per \\
\hline $\mathbf{3 0}$ & 0 & 0 & 0 & $\mathbf{0}$ & 2,30 & 4,54 & 5,45 \\
\hline $\mathbf{3 0}$ & 0 & 0 & 0 & $\mathbf{0}$ & 0 & 1,48 & 0 \\
\hline & & & & & & & $\mathrm{p}=0,146$ \\
\hline
\end{tabular}

\begin{tabular}{|c|c|c|c|c|c|c|c|}
\hline \multirow{2}{*}{ VAS } & \multicolumn{7}{|c|}{$\begin{array}{c}\text { synovitis in medial } \\
\text { recess (mm) }\end{array}$} \\
\cline { 2 - 9 } & 5-ti per & 10-ti per & 25-ti per & medijan. & 75-ti per & 90-ti per & 95-ti per \\
\hline $\mathbf{3 0}$ & 0 & 0 & 0 & $\mathbf{0}$ & 0 & 2,83 & 3,76 \\
\hline $\mathbf{3 0}$ & 0 & 0 & 0 & $\mathbf{0}$ & 0 & 0 & 0 \\
\hline & & & & & & & $\mathrm{p}=0,049$ \\
\hline
\end{tabular}

\begin{tabular}{|c|c|c|c|c|c|c|c|}
\hline \multirow{2}{*}{ VAS } & \multicolumn{7}{|c|}{$\begin{array}{c}\text { synovitis in lateral } \\
\text { recess (mm) }\end{array}$} \\
\cline { 2 - 9 } & 5-ti per & 10-ti per & 25-ti per & medijan. & 75-ti per & 90-ti per & 95-ti per \\
\hline $\mathbf{3 0}$ & 0 & 0 & 0 & $\mathbf{1 , 8 8}$ & 3,55 & 5,82 & 7,06 \\
\hline$\leq \mathbf{3 0}$ & 0 & 0 & 0 & $\mathbf{0}$ & 2,52 & 3,06 & \\
\hline & & & & & & & $\mathrm{p}=0,054$ \\
\hline
\end{tabular}

Table 3. Comparation average value of a quantity of synovitis in suprapatellar, medial and lateral recess between the patients with pain scores greater and lower than $30 \mathrm{~mm}$ on VAS pain scale

\subsubsection{Ultrasound diagnostics of destructive changes in osteoarthrosis}

The ultrasound parameters of cartilage and bone destructions are the reduced thickness of cartilage and detected osteophytes and bone erosions.

The cartilage and bone damages progress with the age and the duration of disease.

In the knee osteoarthrosis, cartilage damages primarily and most excessively occur medially, i.e. degenerative changes are the most intensive in the medial condyle, which complies with the data from literature (Pilipović, 2000).

\subsubsection{Ultrasound diagnosis of the Baker's cyst}

The Baker's cyst is a frequent pathological finding in the knee popliteal area. This research proved that the presence of a Baker's cyst found by a clinical examination depends on the presence and size of effusion. The most frequently, Baker's cyst is found clinically in patients who have serious effusion in the knee. Rarely can the Baker's cyst be palpated and found in the popliteal area and in the patients without effusion. Only $8,82 \%$ of patients without effusion had Baker's cyst at the clinical examination, while in over a fourth $(26,5 \%)$ of the patients without clinical signs of effusion, Baker's cyst was found by ultrasound. Only $20 \%$ of patients with clinical diagnosis of the Baker's cyst did not have the cyst at ultrasound examination, while in the majority of patients $(80 \%)$, it was confirmed by ultrasound. In a considerable number of patients (37\%) without clinical signs of Baker's cyst, the cyst was 
proved by ultrasound. This large discrepancy in the frequency of diagnosed Baker's cysts in the knees with osteoarthrosis favorises the arthrosonography as the more precise method in detection of soft tissue deviations in popliteal area.

It was calculated that sensitivity of clinical diagnosis of Baker's cyst was 30,77\% (percentage of the correct diagnosis of Baker's cyst by clinical examination in the group of patients who indeed had the Baker's cyst proved by ultrasound). Specificity of the clinical diagnosis of Baker's cyst was $93,88 \%$ (percentage of diagnosis of Baker's cyst by clinical examination of the group of patients without an ultrasound proven Baker's cyst) (table 4).

\begin{tabular}{|c|c|c|c|c|c|c|}
\hline \multirow{3}{*}{$\begin{array}{c}\text { Baker cyst } \\
\text { clinical } \\
\text { diagnosis }\end{array}$} & \multicolumn{6}{|c|}{ Baker cyst - ultrasound diagnosis } \\
\hline & \multicolumn{2}{|c|}{ absent } & \multicolumn{2}{|c|}{ present } & \multicolumn{2}{|c|}{ total } \\
\hline & $\begin{array}{l}\text { Number } \\
\text { of patient }\end{array}$ & $\%$ & $\begin{array}{l}\text { Number } \\
\text { of patient }\end{array}$ & $\%$ & $\begin{array}{l}\text { Number } \\
\text { of patient }\end{array}$ & $\%$ \\
\hline absent & 46 & 63,01 & 27 & 36,98 & 73 & 100 \\
\hline present & 3 & 20,0 & 12 & 80,0 & 15 & 100 \\
\hline total & 49 & 55,68 & 39 & 44,31 & 88 & 100 \\
\hline & & & & & & $\mathrm{p}=0,003$ \\
\hline
\end{tabular}

Table 4. The relationship of clinical diagnosis of Baker cyst and arthrosonography diagnosis in patients with knee osteoarhrosis

It was shown that the diagnosis of Baker's cyst at clinical examination mostly depends on its area (size) which can be measured by ultrasound $(\mathrm{p}=0,000)$, and does not depend on any other clinical nor ultrasound parameters.

It was established that occurrence and size of the Baker's cyst depend on the size of effusion and synovitis in SR and LR.

It was not determined that there is a significant difference in the presence or absence of the Baker's cyst at clinical examination between groups of patients with the pain mark over 30 $\mathrm{mm}$ and below $30 \mathrm{~mm}$ on VAS $(\mathrm{p}=0,259)$. In contrast, it was proved that there is a significant correlation between the evaluation by the patients with knee OA on VAS and the Baker's cyst area measured by ultrasound $(\mathrm{r}=0,238, \mathrm{p}=0,025)$, which means that the presence of a larger Baker's cyst in popliteal knee area contributes to stronger pain. These results are in complience with the Hill's research in 2001, which determined that the presence of Baker's cyst is associated with occurrence of pain (Hill et al.,2001).

\subsection{Predisposing factors of the knee osteoarthrosis deterioration}

The main risk factor for knee osteoarthrosis deterioration, apart from overweight and obesity, is occurrence of synovial inflammation, the intensity of which can be measured by arthrosonography, measuring the scope of effusion and synovitis thickness in recessses, especially the lateral recess, as well as by presence and size of Baker's cyst of the bad knee joint. It was not established that the joint destructions (occurrence of osteophyte and bone erosion on tibia and femur condyle) significantly influence the pain intensity increase, unlike synovial inflammation, effusion and synovitis.

\subsection{Biomarkers}

Biomarkers (biochemical markers) are molecules or fragments of connective tissue matrix which disperse into biological fluids during tissue metabolism. Their concentration can be 
measured by immunoassay methods (Garnero et al.,2006). Measuring the concentration of these biomarkers may be complementary with imaging techniques following up the development of diseases such as rheumatoid arthritis and osteoarthrosis (Garnero et al.,2000). It is recommended to measure and simultaneously follow up concentrations of several markers on cartilage, bones and synovial metabolisms, because joining these markers can reflect metabolic changes in all three tissues, showing a better picture of pathophysiological changes in osteoarthrosis (Charni et al.,2005, Garnero et al.,2001). In this research three biomarkers were used: Cartilage Oligomeric Matrix Protein - COMP, human cartilage glycoprotein (YKL-40) known as the Human Cartilage Glycoprotein 39 (HC gp-39 or GP-39) and Collagen type I C - terminal telopeptide (CTX-I).

Cartilage Oligomeric Matrix Protein - COMP is a non-collagen protein of articular cartilage matrix (Clark et al.,1999). It is synthetised by chondrocites and synovial cells after activation of proinflammatory cytokines. This protein is an ingredient of collagen, type II, and it stimulates and regulates fibryllogenesis and stabilises collagen net in cartilage tissue. It is useful as a marker of early cartilage destruction, because it is first emmited in the process of collagen net splitting, which results in cartilage deterioration (Larson et al.,2004).

Human cartilage glycoprotein (YKL-40) is a glycoprotein with molecular mass 38-40 kDa. It has a significant role in tissue remodelling, including the joint cartilage. YKL-40 is synthetised and secreted by hondrocites and synovial cells, also by activated macrophages, liver fibrocytes and colon, breast, lung, ovary and prostate cancer cells (Hakala et al.,1993,Register et al.,2001), as well as osteosarcoma cells (MG-63) (Johansen et al.,1993). It is not known what is the biological function of YKL-40 in malignant tumors, but it has been proven that this glycoprotein stimulates growth of connective tissue cells and chemotaxis. In persons with healthy cartilage, the level of YKL-40 in serum is low, while in the conditions of inflammation or extracellular matrix remodeling, there is a considerable increase in the level of this glycoprotein (Johansen et al.,2001,Volck et al.,1999). For these reasons YKL-40 can be used as a marker of cartilage and synovial tissue metabolism (Harvey et al.,1998). Collagen, type I, and non-collagen proteins are biomarkers of bone tissue metabolism. Researches of Rovetta et al (Rovwtta et al.,2003) showed much higher values of the collagen type I - CTX-I decomposition product in the serum of the patients with the errosive hand osteoarthrosis comparing to the patients with non-errosive hand osteoarthrosis. The study by Berger et al showed that the patients with the rapidly destructive osteoarthrosis have higher values of CTX-I in serum than the patients with slightly progressive osteoarthrosis (Berger et al.,2005).

\subsubsection{The knee osteoarthrosis inflammatory change diagnosis by biomarkers}

The joint inflammation in osteoarthrosis is usually mild and does not disturb the parameters of inflammation acute phase, but can be proved by the serum markers which indicate synovial activities (Garnero et al.,2001,2003,Kraus,2005). Metabolic changes of cartilage tissues in arthroses imply changes in matrix synthesis and degradation, and matrix molecules are excreted as fragments into the joint liquid, blood and urine, where they can be detected and measured (Lohmander,2004).

In this research, the concentration of the biomarkers COMP, YKL-40 and CTX-I was measured in serum of the patients with knee osteoarthrosis. Comparing to effusion scope (minimal, moderate or serious), considerable difference in average values of COMP, YKL-40 and CTX-I biomarker concentration ( $\mathrm{p}=0,361, \mathrm{p}=0,690$ and $\mathrm{p}=0,108$, respectively) was not found, probably because of insufficient sensitivity of clinical examination in detection of synovial inflammation. 
Significant difference of COMP biomarkers average values in serum was indicated, depending on presence of effusion during ultrasound examination, regardless its location and size. The patients with effusion in the knee have higher COMP concentrations in serum, comparing to the patients without effusion detected by ultrasound (Table5.). That implies that increased COMP concentration in serum can be a good indicator of synovial inflammation in the knee joint arhrosis (Živanović et al.,2009).

\begin{tabular}{|c|c|c|c|c|c|}
\hline \multirow{2}{*}{ EFFUSION } & Number of & Percentage & \multicolumn{3}{|c|}{ COMP (ng/mL) } \\
\cline { 4 - 6 } & subjects & of subjects & \multicolumn{3}{|c|}{ Median } \\
\cline { 4 - 6 } & $\mathbf{N}$ & $\%$ & 25 -th perc. & 50 -th perc. & 75-th perc. \\
\hline present & 22 & 25.0 & 44.50 & 54.00 & 58.00 \\
\hline absent & 66 & 75.0 & 48.75 & 57.00 & 64.25 \\
\hline
\end{tabular}

\begin{tabular}{|c|c|c|c|c|c|}
\hline \multirow{3}{*}{ SYNOVITIS } & \multirow{3}{*}{$\begin{array}{c}\text { Number of } \\
\text { subjects } \\
\mathbf{N} \\
\end{array}$} & \multirow{3}{*}{$\begin{array}{c}\text { Percentage } \\
\text { of subjects } \\
\% \\
\end{array}$} & \multicolumn{3}{|c|}{ COMP (ng/mL) } \\
\hline & & & \multicolumn{3}{|c|}{ Median } \\
\hline & & & 25-th perc. & 50-th perc. & 75-th perc. \\
\hline present & 29 & 33.0 & 45.5 & 52.0 & 58.0 \\
\hline absent & 59 & 67.0 & 50.0 & 58.0 & 66.0 \\
\hline
\end{tabular}

Table 5. Comparison of the median of the concentration of COMP biomarker between patients with present or absent effusion and prolipheration of synovial membrane

It was also found that there was a significant difference in serum COMP biomarker concentration average values between the patients with and without synovial membrane proliferation found by ultrasound, regardless the location and size. This evidence implies the fact that COMP biomarker values increase in serum when the knee joint inflammation is present as synovial membrane hypertrophy. However, COMP biomarker values can only confirm existence of synovial inflammation, i.e. detect it. Its increased concentrations cannot precisely determine inflammation degree (size) nor its location (in recess).

A research related to synovitis type showed that there is a significant difference in COMP average concentrations in serum in patients with nodular, diffusive or nodular-deffusive synovitis. Highest COMP concentrations in serum were determined in patients with diffusive synovitis, which confirms the fact that diffusive proliferative synovitis causes the most intensive inflammation, if it occurs in the knee joint arthrosis (Figure 6.).

The patients with knee artrosis accompanied with knee effusion and synovitis, have higher concentrations of COMP biomarkers in serum, than the patients without ultrasound indicators of synovial inflammation, which confirms that COMP can be a good indicator of synovial inflammation.

During researches of sensitivity and specificity by ROC graph (Receiver Operating Characteristic) it was found that among analysed serum parameters only COMP parameter can be an indicator of effusion in the knee joint. COMP biomarker sensitivity on effusion was $59 \%$, and its specificity $50 \%$ (cut off $=53,5$; area 0,$665 ; p=0,030$; confidence interval 0,534 $0,776)$. Cut off value was found to be $53,5 \mathrm{ng} / \mathrm{ml}$, which means that no patients with osteoarthrosis and COMP biomarker concentrations in serum below 53,5 ng/ml have knee joint inflammation, while COMP biomarker values above $53,5 \mathrm{ng} / \mathrm{ml}$ indicate presence of inflammation. It means that the Cartilage matrix oligomeric protein have a moderate signifficance at effusion presence estimation (Figure 7.) (Zivanović et al.,2011). 


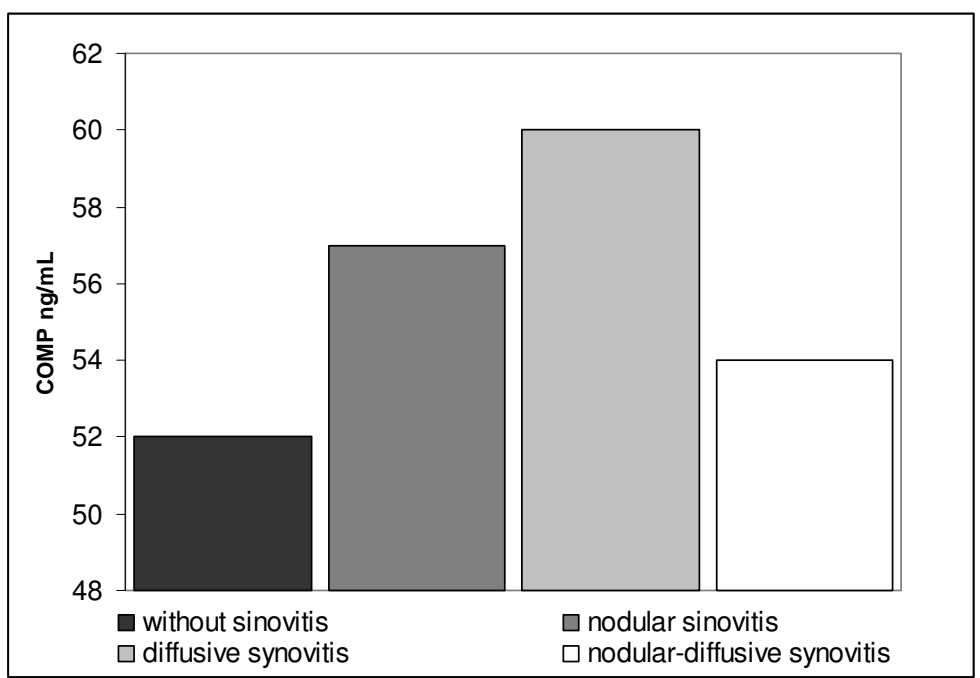

Fig. 6. Comparation of median of COMP biomarker concentration between patients with nodular, diffusive or nodular-difussive synovitis $(p=0,014)$

\section{ROC Curve}

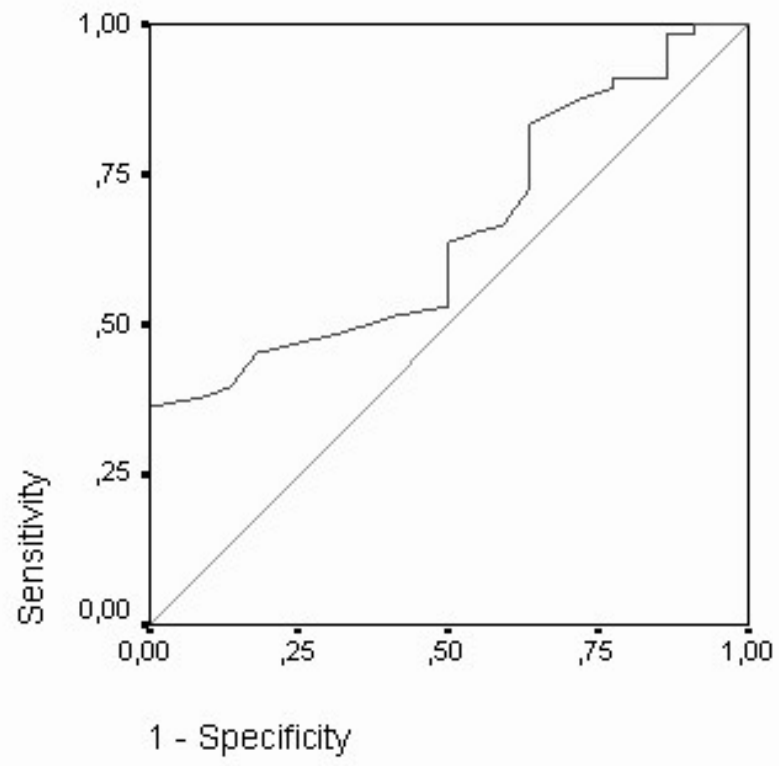

Diagonal segments are produced by ties.

Fig. 7. Cartilage Matrix Oligomeric Protein as a marker of the effusion cut off $=53.5 \mathrm{ng} / \mathrm{mL}$; Area $0.655 ; p=0.030$; confidence interval 0.534-0.776 
It was not proved for any of the investigated markers that they could be indicators of the synovial membrane i.e. synovitis proliferation. Presented results of the research did not confirm significant correlation between mean values of YKL-40 and CTX-I biomarkers with inflammation (effusion and/or synovitis) in the knees with arthrosis.

\subsubsection{Diagnosis of destructive changes of the knee with osteoarthrosis by biomarkers}

The results of this research indicated the negative correlation between YKL-40 values in serum and cartilage thickness on the medial femur condyle (front view). It showed that YKL-40 increased concentrations are associated with reduced thickness of the knee joint cartilage, especially medially, and vice versa (Table 6.). At the finding of a thinning cartilage, especially on the medial femur condyle, high values of YKL-40 in serum can be expected in patients with knee osteoarthrosis. As in the early phase of knee arthrosis the destructive changes on the joint cartilage dominantly occur on the medial tibia and femur condyle, it can be concluded on the bases of the provided results that increased concentrations of YKL40 in serum can be a good indicator of early damage of joint cartilage (Živanović et al.,2009).

\begin{tabular}{|c|c|c|c|c|c|c||}
\hline \multirow{2}{*}{$\begin{array}{c}\text { cartilage } \\
\text { thickness } \\
\text { (mm) }\end{array}$} & \multicolumn{6}{|c|}{ concentration of biomarkers (ng/ml) } \\
\cline { 2 - 7 } & $\mathrm{r}$ & $\mathrm{p}$ & $\mathrm{r}$ & $\mathrm{p}$ & $\mathrm{r}$ & $\mathrm{p}$ \\
\cline { 2 - 7 } & COMP & $\mathbf{4 0}$ & $\mathbf{0}$ & $\mathbf{0}$ \\
\hline $\begin{array}{c}\text { medial.condil } \\
\text { front access) }\end{array}$ & $-0,177$ & 0,099 & $\mathbf{- 0 , 2 4 9}$ & $\mathbf{0 , 0 1 9}$ & $-0,043$ & 0,691 \\
\hline $\begin{array}{c}\text { medial.condil } \\
\text { (back access) }\end{array}$ & $-0,184$ & 0,087 & $-0,056$ & 0,608 & $-0,018$ & 0,866 \\
\hline $\begin{array}{c}\text { lateral.condil } \\
\text { front access) }\end{array}$ & $-0,067$ & 0,538 & $-0,080$ & 0,460 & $-0,087$ & 0,423 \\
\hline
\end{tabular}

Table 6. Correlation between serum concentration of biomarkers COMP, YKL 40 and CTX I with cartilage thickness (mm) in the medial (front and back access) and lateral (front access) femur condyles

Correlation of other biomarkers' concentrations with the size of joint cartilage was not proved, so that it can be concluded on the basis of the provided results that their increased concentrations in the patients' serum cannot be a good parameter for the joint cartilage damage degree in patients with knee joint osteoarthrosis (Živanović et al.,2009).

This research shows that there is a considerable difference in COMP and YKL-40 biomarkers concentration mean values between the patients with shorter and longer osteophytes on tibia and femur condyles $(p=0,000)$ (Table 7.,8.).

\begin{tabular}{|c|c|c|c|c|c|}
\hline \multirow{2}{*}{ OSTEOPHYTES } & \multirow{2}{*}{$\begin{array}{c}\text { Number of } \\
\text { subjects }\end{array}$} & \multirow{2}{*}{$\begin{array}{c}\text { Percentage } \\
\text { of subjects } \\
\%\end{array}$} & \multicolumn{3}{|c|}{ mid.value COMP $(\mathrm{ng} / \mathrm{ml})$} \\
\cline { 4 - 6 } & $\mathrm{N}$ & & $25^{\text {th }}$ perc. & Median & $75^{\text {th }}$ perc. \\
\hline Shorter & 21 & 23,9 & 46,5 & $\mathbf{5 5 , 0}$ & 59,0 \\
\hline Longer & 67 & 76,1 & 48,0 & $\mathbf{5 6 , 0}$ & 64,0 \\
\hline & & & & & $p=0,000$ \\
\hline
\end{tabular}

Table 7. Comparison of the median of the concentration of biomarker COMP between patients with shorter and longer osteophytes. 


\begin{tabular}{|c|c|c|c|c|c|}
\hline \multirow{2}{*}{ OSTEOPHYTES } & \multirow{2}{*}{$\begin{array}{c}\text { Number of } \\
\text { subjects }\end{array}$} & \multirow{2}{*}{$\begin{array}{c}\text { Percentage } \\
\text { of subjects } \\
\%\end{array}$} & \multicolumn{3}{|c|}{ mid.value YKL $40 \quad(\mathrm{ng} / \mathrm{ml})$} \\
\cline { 4 - 6 } & $\mathrm{N}$ & & $25^{\text {th }}$ perc. & Median & $75^{\text {th }}$ perc. \\
\hline Shorter & 21 & 23,9 & 44,5 & $\mathbf{6 2 , 0}$ & 90,0 \\
\hline Longer & 67 & 76,1 & 80,0 & $\mathbf{1 1 9 , 0}$ & 171,0 \\
\hline & & & & & $p=0,000$ \\
\hline
\end{tabular}

Table 8. Comparison of the median of the concentration of biomarker YKL40 between patients with shorter and longer osteophytes.

Osteophytes and bone erosions occur as consequence of damage and loss of cartilage tissue accompanied with cartilage destruction, and indirectly reflect the damage degree. Increased concentration of YKL-40 biomarker can be an indicator of destructive changes degree in the knee osteoarthrosis. That indicates a possibility of using this marker to estimate the joint destruction (Živanović et al.,2009).

Conclusions of this research comply with the results by Johansen et al (Johansen et al.,1996) which showed that in the patients at later stage of knee osteoarthrosis there is an increased level of YKL-40 in serum. Contrary to that, Garnero's study (Garnero,2001) did not prove high concentrations of YKL-40 in patients with the late-stage osteoarthrosis (Figure 8.).

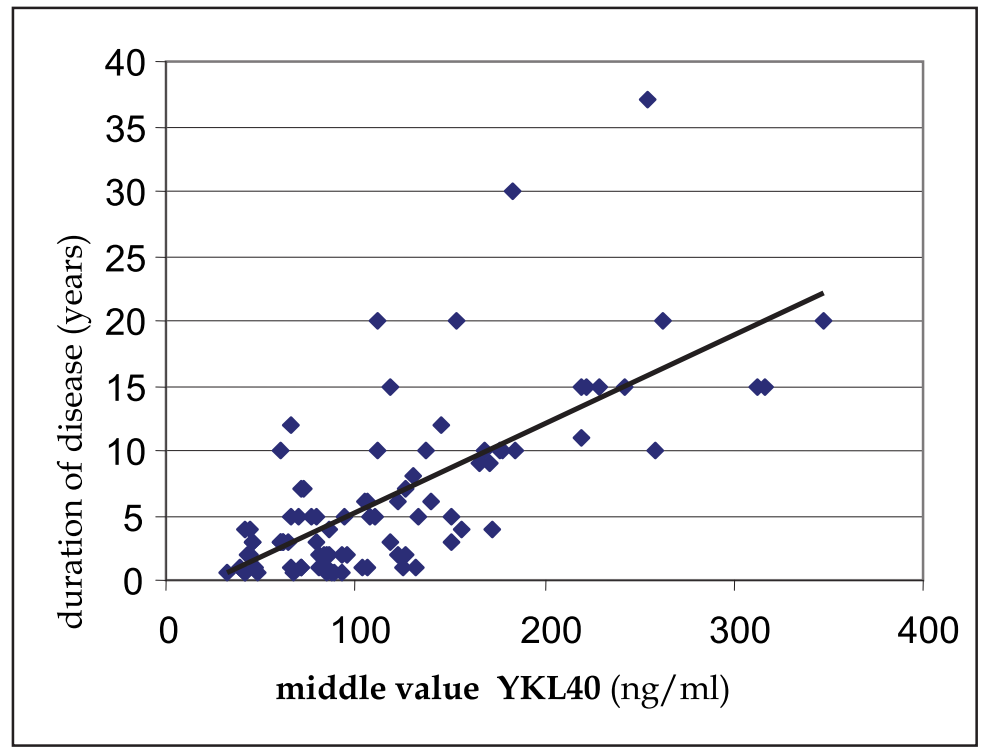

Fig. 8. Link between the middle value (median) of biomarker YKL40 and duration of the knee OA $(r=0,651, p=0,000)$

This research results showed that YKL-40 biomarker can be a highly sensitive marker of occurrence of longer osteophytes. Sensitivity of YKL-40 concentration in serum on occurrence of longer osteophytes on tibia and femur condyles is $79,1 \%$, and its specificity $61,9 \%$ (cut off 75,0; area 0,806; $\mathrm{p}=0,000$; confidence interval 0,706-0,906). The cut off value $75,0 \mathrm{ng} / \mathrm{ml}$ indicates that all the patients with osteoarthrosis and serum YKL-40 values 
below 75,0 ng/ml have milder degree of joint destruction comparing to the patients with YKL-40 value above $75,0 \mathrm{ng} / \mathrm{ml}$ who have higher-degree joint destruction and the presence of longer osteophytes in the knee joint (Figure 9.) (Živanović et al.,2009).

\section{ROC Curve}

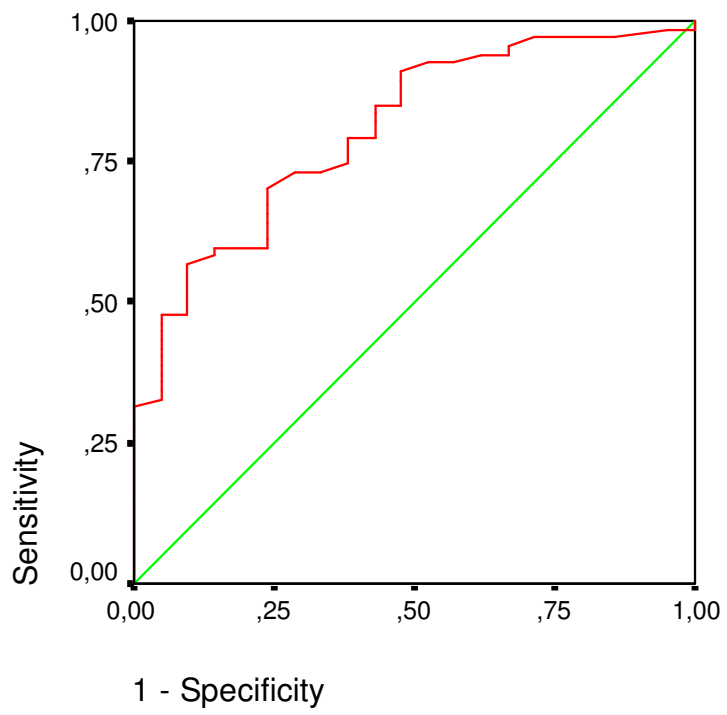

Diagonal segments are produced by ties.

cut off $=75,0$; Area 0,806; $\mathrm{p}=0,000$; confidence interval 0,706-0,906

Fig. 9. YKL 40 as a marker for appearance of longer osteophytes at the tibia and femur condyles

It was found that there is a considerable diference of YKL-40 mean values depending on the presence or absence of bone erosions on tibia and femur condyles (Table 9) (Živanović et al.,2010)

\begin{tabular}{|c|c|c|c|c|}
\hline & Bone erosion & 25-th per & median & 75-th per \\
\hline \multirow{2}{*}{$\begin{array}{c}\text { COMP } \\
(\mathrm{ng} / \mathrm{ml})\end{array}$} & absent & 46 & 55 & 59,50 \\
\cline { 2 - 5 } & present & 48 & 57 & 63 \\
\hline & & & & $\mathrm{p}=0,483$ \\
\hline $\begin{array}{c}\text { YKL-40 } \\
(\mathrm{ng} / \mathrm{ml})\end{array}$ & absent & 46,50 & $\mathbf{8 1}$ & 120,50 \\
\hline & present & 79 & $\mathbf{1 1 1}$ & 171 \\
\hline & & & 0,93 & $\mathrm{p}=0,004$ \\
\hline \multirow{2}{*}{$\begin{array}{c}\text { CTX-I } \\
(\mathrm{ng} / \mathrm{ml})\end{array}$} & absent & 0,71 & 0,83 & 1,10 \\
\cline { 2 - 5 } & present & 0,64 & 1,11 \\
\hline
\end{tabular}

Table 9. Comparation of median) concentrations of biomarkers between patients with present or absent bone erosions 
Higher concentration of YKL-40 in serum can be found when there is a severe destruction of bones at the joint edges. The highest YKL-40 values were found in patients with erosions on the medial condyles (Figure 10.) (Živanović et al.,2010).

COMP and CTX-I biomarkers are not good indicators (markers) of erosions on tibia and femur condyles, unlike YKL-40 which can be a good indicator of erosions (Figure 11.).

YKL-40 sensitivity on occurrence of erosions on tibia and femur condyles is $69,5 \%$, and its specificity is $51,7 \%$ (cut off $=84,5$; area 0,$691 ; p=0,004$; confidence interval $0,574-0,808$ ). It was found that the cut off is $84,5 \mathrm{ng} / \mathrm{ml}$, which means that all the patients with osteoarthrosis YKL-40 value below $84,5 \mathrm{ng} / \mathrm{ml}$ have milder degree of destruction without occurrence of bone erosions, and that YKL-40 values above $84,5 \mathrm{ng} / \mathrm{ml}$ indicate higher degree of the joint destruction which implies bone erosion (Figure12.) (Živanović et al.,2010).

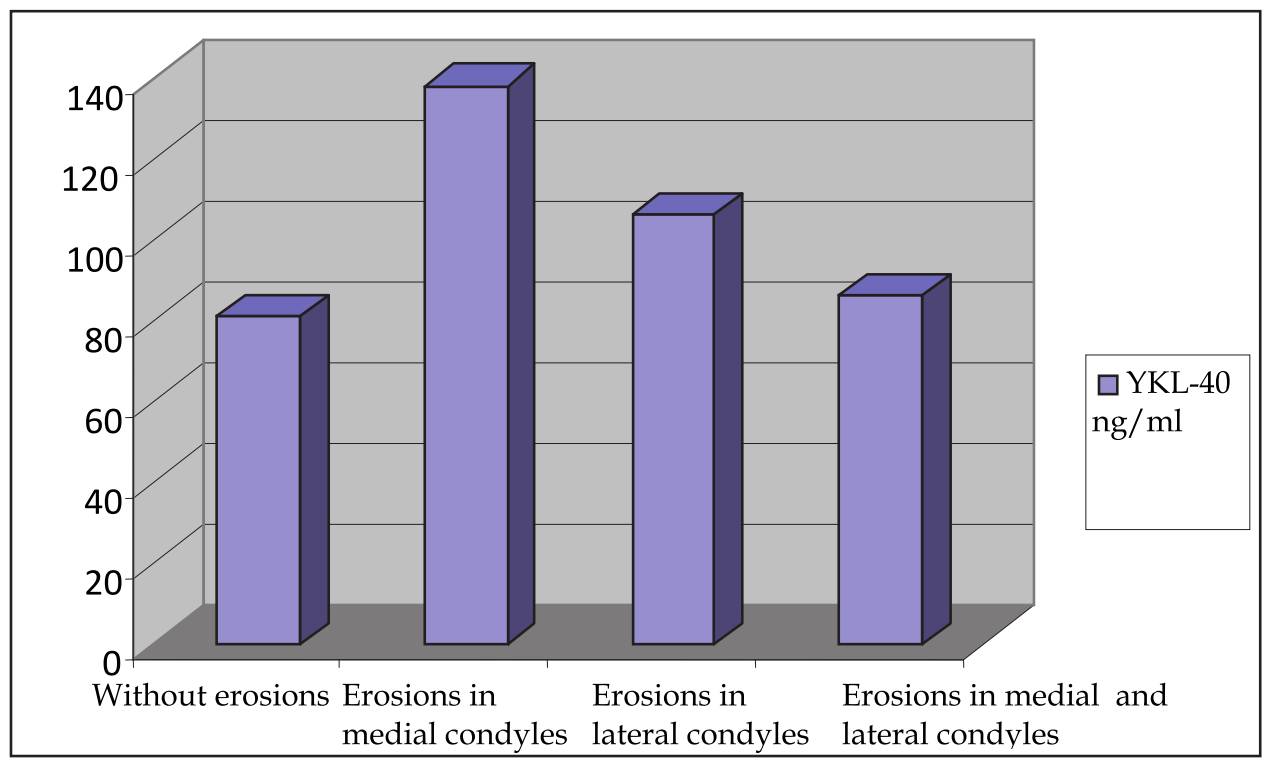

Fig. 10. Differences in mean values (median) of biomarkers YKL-40 concentration in patients with present or absent erossions on the medial and/or lateral the tibia and femoral condyles 
ROC Curve

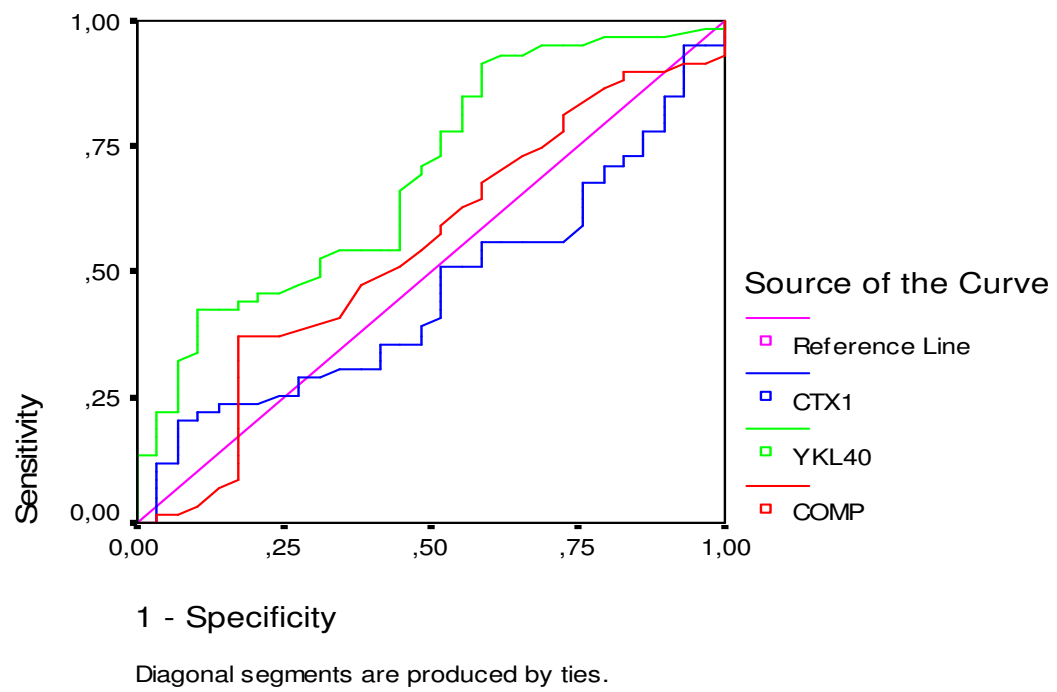

Fig. 11. Biomarkers COMP, YKL-40 and CTX-I as a markers to appear bone erossion in the condyles of the tibia and femur

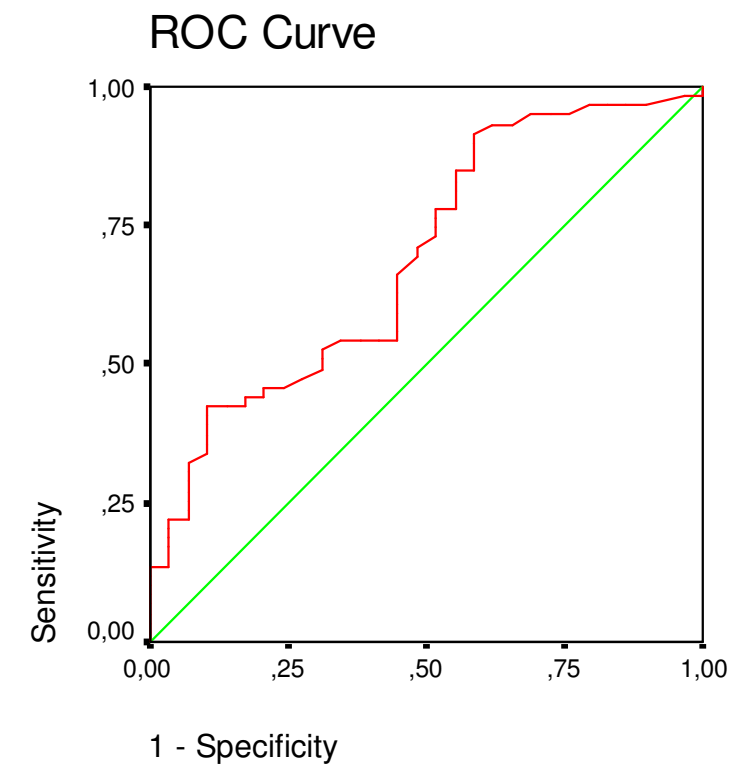

Diagonal segments are produced by ties.

Fig. 12. Biomarker YKL 40 as a marker to appear bone erossion in the condiles of tibia and femur 
The results of this research comply with the research results of Morgante et al (Morgante et al.,2001) who determined that YKL-40 is a good prognostic marker of joint destruction. On the other hand, Kawasaki's study showed different evidence related to hip osteoarthrosis. YKL-40 value in serum is a better indicator of synovial inflammantion degree than of the cartilage tissue metabolism (Kawasaki et al.,2001).

In this research the results of multivariant binary logistic regression show that the duration of disease is related to YKL-40 biomarker values in serum. Comparing the YKL-40 concentration mean values with reference to $5,10,15$ and 20 years duration of the disease, considerable differences were determined $(p=0,000)$. YKL-40 biomarker mean value increases with disease duration (Figure 13.) (Živanović et al.,2009).

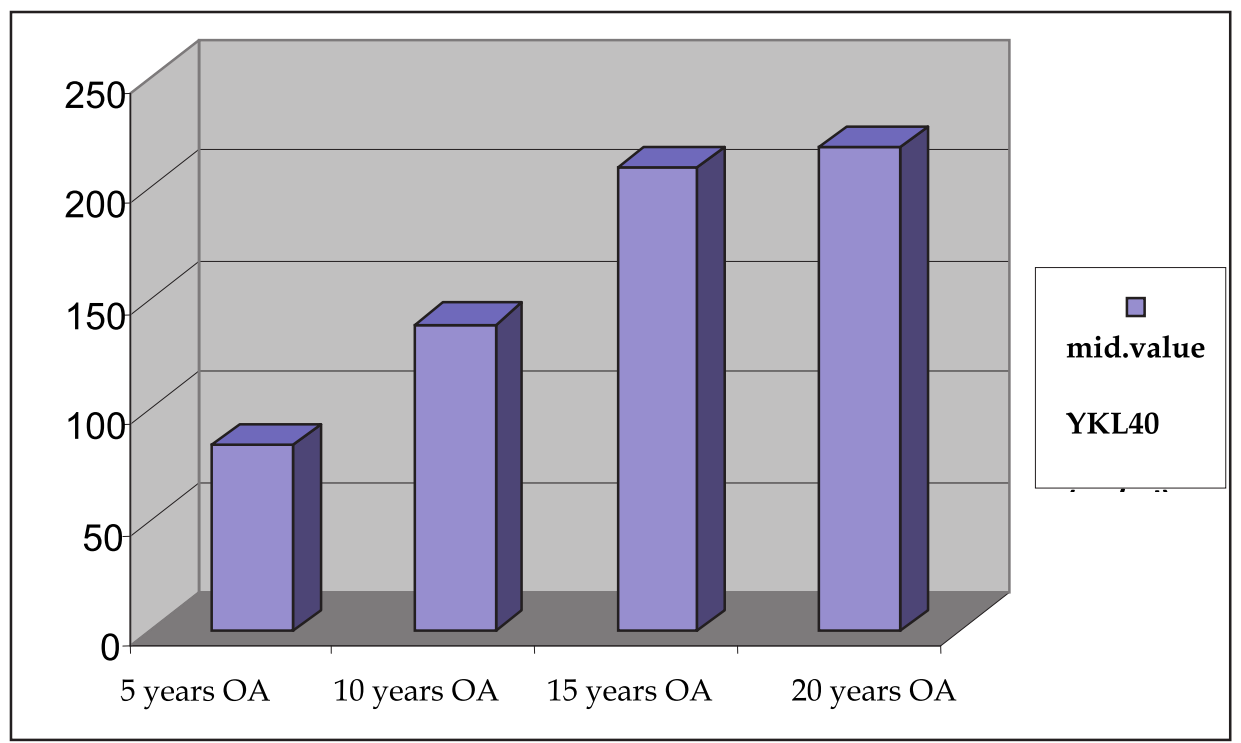

Fig. 13. Increase in concentration of YKL40 for the duration of knee osteoarthrosis (after 5, 10,15 i 20 years)

In the patients with a long-lasting knee arthrosis and with progressed degenerative changes, osteophytes and bone erosions, higher concentrations of YKL-40 can be found in serum. That proves that YKL-40 biomarker can be a valid indicator of knee osteoarthrosis destructive changes (Živanović et al.,2009).

\subsubsection{Biomarkers as indicators of the pain degree and knee osteoarthrosis deterioration}

Analysis and comparation of the biomarkers concentration in serum between a group of patients with deterioration of knee osteoarthrosis and a group of patients without deterioration have been conducted.

The patients with deterioration of knee osteoarthrosis have similar biomarker concentration values as the patients without symptoms and signs of the disease deterioration. Correlation between VAS mean values and concentration of investigated biomarkers was not proven either. That indicates that values of investigated biomarkers cannot be valid indicators of 
pain intensity nor manifestation of disease deterioration in patients with knee osteoarthrosis.

\section{Conclusion}

This study has shown advantages of arthrosonography which distinguish it from the other methods of visualisation, especially at estimation of the knee osteoarthrosis deterioration. The disease deterioration, i.e. sudden intensification of pain the patients undergo is associated with the finding of synovial inflammation at the knee arthrosonography, as well as with presence of the Baker's cyst in the knee popliteal fossa.

It is emphasised that arthrosonography is a more sensitive method than clinical examination at identification of location and size of effusion and synovial proliferation in the knee joint osteoarthrosis, as well as at detection and estimation of Baker's cyst size, especially in patients with intensive pain but without clinical singns of effusion or Baker's cyst existence. This study presents serum biomarkers as detectors of inflammatory and destructive changes in the knee joint with osteoarthrosis. It is recommended to measure Cartilage Oligomeric Matrix Protein - COMP concentration in serum for estimation of synovial inflammation, and Human Cartilage Glycoprotein 39 - YKL-40 at estimation of joint and bone cartilage damage.

Application of biomarkers as a diagnostic method is much more expensive than arthrosonography, which means that it is not accessible to all the patients. It takes a couple of days to get results on concentration of biomarkers in serum, thus it cannot be said that it is a quick method. Some patients feel uneasy when giving blood sample for tests, which makes the method relatively aggressive and it is not possible to repeat it often. It should also be emphasised that measuring of biomarker concentration in serum does not provide precise data on size and location of inflammatory and destructive changes in the knee joint with osteoarthrosis, but only detects them.

On the other hand, the advantages of arthrosonography that distinguish it from the other diagnostic methods are accessibility and low price, noninvasiveness, quick and precise presentation of both normal and patological soft-tissue structures, as well as possibility of frequent repetitions. The quality of ultrasound examination depends on technical equipment and of the doctor's experience. Anyway, standardisation of the equipment and expert knowledge usually produce a good-quality examination.

This study recommends that arthrosonography should become routine and fundamental method in contemporary rheumatological practice, and a complement to clinical examinations.

\section{References}

Batalov AZ, Kuzmanova SI, Penev DP. Ultrasonographic evaluation of knee joint cartilage in rheumatoid arthritis patients.Folia Med (Plovdiv). 2000;42(4):23-6.

Berger C,Kröner A,Stiegler H, ThomasLeitha T,Engel A. Elevated levels of serum type I collagen C-telopeptide in patients with rapidly destructive osteoarthritis of the hip. International Ortopaedics. 2005; 29(1):1-5.

Charni N, Juillet F, Garnero P. Urinary type II collagen helical peptide (Helix II) as a new biochemical marker of cartilage degradation in patients with osteoarthritis and rheumatoid arthritis. Arthritis Rheum 2005;52:1081-90. 
Clark AG, Jordan JM, Vilim V, Renner JB, Dragomir AD, Luta G, et al. Serum cartilage oligomeric matrix protein reflects osteoarthritis presence and severity. Arthritis Rheum 1999;42:2356-2364.

Conaghan P, D'Agostino MA, Ravaud P, Baron G, Le Bars M, Grassi W, Martin-Mola E, Wakefield R, Brasseur JL, So A, Backhaus M, Malaise M, Burmester G, Schmidely N, Emery P, Dougados M. EULAR report on the use of ultrasonography in painful knee osteoarthritis. Part 2: exploring decision rules for clinical utility. Ann Rheum Dis. 2005 Dec;64(12):1710-4. Epub 2005 May 5.

D'Agostino MA, Conaghan P, Le Bars M, Baron G, Grassi W, Martin-Mola E, Wakefield R, Brasseur JL, So A, Backhaus M, Malaise M, Burmester G, Schmidely N, Ravaud P, Dougados M, Emery P. EULAR report on the use of ultrasonography in painful knee osteoarthritis. Part 1: prevalence of inflammation in osteoarthritis. Ann Rheum Dis. 2005 Dec;64(12):1703-9. Epub 2005 May 5.

Dougados M. La mesure: méthodes d'évaluation des affections rhumatismales. Paris: Expansion Scientifique, 1997.

Garnero P, Delmas PD. Biomarkers in osteoarthritis. Curr Opin Rheumatol 2003;15:641-6.

Garnero P, Piperno M, Gineyts E, Christgau S, Delmas PD, Vignon E. Cross sectional evaluation of biochemical markers of bone, cartilage, and synovial tissue metabolism in patients with knee osteoarthritis: relations with disease activity and joint damage. Ann Rheum Dis 2001;60:619-26.

Garnero P, Rousseau J-C, Delmas P. Molecular basis and clinical use of biochemical markers of bone, cartilage and synovium in joint diseases. Arthritis Rheum 2000;43:953-961.

Garnero P, N Charni, F Juillet, T Conrozier and E Vignon . Increased urinary type II collagen helical and $\mathrm{C}$ telopeptide levels are independently associated with a rapidly destructive hip osteoarthritis Annals of the Rheumatic Diseases 2006;65:1639-1644.

Hakala BE, White C, Recklies AD. Human cartilage gp-39, a major secretory product of articular chondrocytes and synovial cells, is a mammalian member of a chitinase protein family. J Biol Chem 1993;293:781-788.

Hart DJ, Doyle DV, Spector TD. Incidence and risk factors for radiographic knee osteoarthritis in middle-aged women, the Chingford Study. Arthritis Rheum 1999;42:17-24.

Harvey, S. et al. Clin. Chem. 44: 509-516, 1998.

Hill CL, Gale DG, Chaisson CE, Skinner K, Kazis L, Gale E, et al. : Knee effusion, popliteal cysts, and synovial thickening: association with knee pain in osteoarthritis. J Rheumatol 2001;28:1330-7.

Johansen JS, Hvolris J, Hansen M, Backer V, Lorenszen I, Price PA. Serum YKL-40 levels in healthy children and adults. Comparison with serum and synovial fluid levels of YKL-40 in patients with osteoarthritis or trauma of the knee joint. Br J Rheumatol 1996;35:553-559.

Johansen JS, Jensen HS, Price PA.A new biochemical marker for joint injury. Analysis of YKL-40 in serum and synovial fluid. Br J Rheumatol. 1993 Nov;32(11):949-55.

Johansen JS, Olee T, Price PA, Hashimoto S, Ochs RL, Lotz M. Regulation of YKL-40 production by human articular chondrocytes. Arthritis Rheum. 2001 Apr;44(4):82637. 
Kane D, Balint PV, Sturrock RD. Ultrasonography is superior to clinical examination in the detection and localization of knee joint effusion in rheumatoid arthritis. J Rheumatol. 2003 May;30(5):966-71 Comment in: J Rheumatol. 2003 May;30(5):908-9.

Kawasaki M, Hasegawa Y, Kondo S, Iwata H. Concentration and localization of YKL-40 in hip joint diseases. J Rheumatol. 2001 Feb;28(2):341-5.

Kraus VB. Biomarkers in osteoarthritis. Curr Opin Rheumatol 2005;17:641-6.

Larsson E, Erlandsson Harris H, Larsson A, Månsson B, Saxne T, Klareskog L. Corticosteroid treatment of experimental arthritis retards cartilage destruction as determined by histology and serum COMP. Rheumatology (Oxford) 2004;43:42834.

Lohmander LS. Markers of altered metabolism in osteoarthritis. J Rheumatol 2004;31 (Suppl 70) :28-353.

Morgante M, Metelli MR, Morgante D.Observations on the increased serum levels of YKL40 in patients with rheumatoid arthritis and osteoarthritis Minerva Med. 2001 Jun;92(3):151-3.

Pilipović N. Reumatologija; Beograd 2000.

Register, T.C. et al. Clin. Chem. 47: 2159-2161, 2001.

Reijman M, Pols H A P, Bergink A P, Hazes J M W, Belo JN, Lievense AM, Bierma-Zeinstra S M A Body mass index associated with onset and progression of osteoarthritis of the knee but not of the hip: The Rotterdam Study Annals of the Rheumatic Diseases 2007;66:158-162.

Rovetta G, Monteforte P, Grignolo MC, Brignone A, Buffrini L.Hematic levels of type I collagen C-telopeptide in erosive versus nonerosive osteoarthritis of the hands.Int J Tissue React. 2003;25(1):25-8.

Volck B, Ostergaard K, Johansen JS, Garbarsch C, Price PA.The distribution of YKL-40 in osteoarthritic and normal human articular cartilage. Scand J Rheumatol. 1999;28(3):171-9.

Živanović S, Nikolić S, Jevtić M. Kocić S. Inflamation in knee osteoarthritis - couse worsening traubles, Medical examination, 2010;LXIII(9-10):668-673

Živanović S, Petrović Rackov Lj, Vojvodić D, Vučetić D. Human cartilage glycoprotein 39biomarker of joint damage in knee osteoarthritis, International Orthopaedics 2009 Aug; Epub 2009 Mar 24. 33(4):1165-70.

Živanović S, Petrović Rackov Lj, Vučetić D, Mijušković Z. Arthrosonography and biomarker Cartilage Oligomeric Matrix Protein in detection of the knee osteoarthrosis effusion, Journal of Medical Biochemistry, 2009; 28(2): 108-15.

Živanović S, Petrović Rackov Lj, Živanović A. Arthrosonography and Biomarkers in the evaluation of destructive knee cartilage osteoarthrosis, Srp. Arch. Celok. Lek. 2009; 137(11-12): 653-8.

Živanović S, Petrović Rackov Lj, Jevtić M, Detection of bone erosiones in knee osteoarthrosis by serum biomarkers, Srp. Arch. Celok. Lek. 2010; 138(1-2): 62-6.

Živanović S, Petrović Rackov Lj, Živanović A, Jevtić M, Nikolić S, Kocić S, Cartilage Oligomeric Matrix Protein - inflamation biomarker in the knee osteoarthritis, Bosnian Journal of Basic Medical Sciences. 2011 Feb;11(1):27-32 


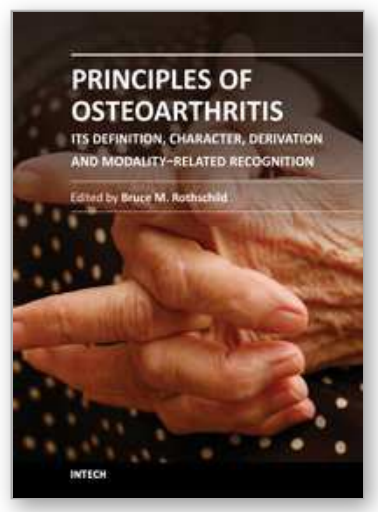

\section{Principles of Osteoarthritis- Its Definition, Character, Derivation and Modality-Related Recognition}

Edited by Dr. Bruce M. Rothschild

ISBN 978-953-51-0063-8

Hard cover, 590 pages

Publisher InTech

Published online 22, February, 2012

Published in print edition February, 2012

This volume addresses the nature of the most common form of arthritis in humans. If osteoarthritis is inevitable (only premature death prevents all of us from being afflicted), it seems essential to facilitate its recognition, prevention, options, and indications for treatment. Progress in understanding this disease has occurred with recognition that it is not simply a degenerative joint disease. Causative factors, such as joint malalignment, ligamentous abnormalities, overuse, and biomechanical and metabolic factors have been recognized as amenable to intervention; genetic factors, less so; with metabolic diseases, intermediate. Its diagnosis is based on recognition of overgrowth of bone at joint margins. This contrasts with overgrowth of bone at vertebral margins, which is not a symptomatic phenomenon and has been renamed spondylosis deformans.

Osteoarthritis describes an abnormality of joints, but the severity does not necessarily produce pain. The patient and his/her symptoms need to be treated, not the x-ray.

\section{How to reference}

In order to correctly reference this scholarly work, feel free to copy and paste the following:

Sandra Živanović, Ljiljana Petrović Rackov and Zoran Mijušković (2012). Biomarkers and Ultrasound in the Knee Osteoarthrosis Diagnosis, Principles of Osteoarthritis- Its Definition, Character, Derivation and ModalityRelated Recognition, Dr. Bruce M. Rothschild (Ed.), ISBN: 978-953-51-0063-8, InTech, Available from:

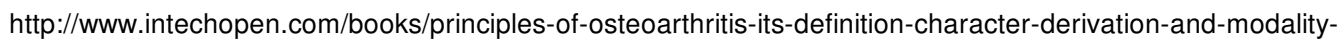
related-recognition/biomarkers-and-ultrasound-in-the-knee-osteoarthrosis-diagnosis

\section{INTECH}

open science | open minds

\section{InTech Europe}

University Campus STeP Ri

Slavka Krautzeka 83/A

51000 Rijeka, Croatia

Phone: +385 (51) 770447

Fax: +385 (51) 686166

www.intechopen.com

\section{InTech China}

Unit 405, Office Block, Hotel Equatorial Shanghai

No.65, Yan An Road (West), Shanghai, 200040, China

中国上海市延安西路65号上海国际贵都大饭店办公楼 405 单元

Phone: +86-21-62489820

Fax: $+86-21-62489821$ 
(C) 2012 The Author(s). Licensee IntechOpen. This is an open access article distributed under the terms of the Creative Commons Attribution 3.0 License, which permits unrestricted use, distribution, and reproduction in any medium, provided the original work is properly cited. 